\title{
PENGARUH PENERAPAN MANAJEMEN MUTU TERHADAP KUALITAS SUMBERDAYA PENDIDIK TPQ DARUSSALAM BLOKAGUNG TEGALSARI BANYUWANGI TAHUN PELAJARAN 2017
}

\author{
Ach. Aminullah \\ Institut Agama Islam Darussalam (IAIDA) Banyuwangi \\ Email: amin.jjg@gmail.com
}

\begin{abstract}
This research aims to: (1) the effect of the application of quality management TPQ Darussalam Blokagung Blokagung Tegalsari Banyuwangi,(2) Mengeahui quality educator resources Darussalam TPQ Blokagung Blokagung Tegalsari Banyuwangi, (3) the effect application quality management to quality educator resources Darussalam TPQ Blokagung Tegalsari Banyuwangi. In this study using a quantitative descriptive method by using product moment on the validity of test data and to search for data reliability using alpha formula, whereas in the hypothesis testing using the F test and t-test then for the data analysis techniques using normality test using regression models. The study population was the guardian of students TPQ Darussalam totaled 250. To measure the variables, the researchers used questionnaires to variations in methods of teaching and learning motivation. After analyzing the data collected, it was found that (1) the application of quality management TPQ Darussalam Blokagung Tegalsari good Banyuwangi. (2) the quality of educator resources Darussalam TPQ Blokagung Tegalasari excellent Banyuwangi. (3) No effect on the Quality of Implementation Quality Management Resource Educator TPQ Darussalam Blokagung Tegalsari Banyuwangi in the school year 2017 was 36.3\%.
\end{abstract}

\section{Keywords: Quality Management, Resource Educator}

\begin{abstract}
Abstrak
Penelitian ini bertujuan untuk:(1) pengaruh penerapan manajemen mutu TPQ Darussalam Blokagung Blokagung Tegalsari Banyuwangi, (2) Mengeahui kualitas sumber daya pendidik TPQ Darussalam Blokagung Blokagung Tegalsari Banyuwangi, (3) mengetahui pengaruh panerapan manajemen mutu terhadap kualitas sumber daya pendidik TPQ Darussalam Blokagung Tegalsari Banyuwangi. Dalam penelitian ini menggunakan metode deskriptif kuantitatif dengan teknik product moment pada uji validitas data dan untuk mencari reliabilitas data menggunakan rumus alpha, sedangkan pada uji hipotesis menggunakan uji $F$ dan uji $t$ kemudian untuk teknik analisis data menggunakan uji normalitas dengan menggunakan model regresi. Populasi penelitian ini adalah wali santri TPQ Darussalam berjumlah 250. Untuk mengukur variabel, peneliti menggunakan kuesioner untuk variasi metode mengajar dan motivasi belajar. Setelah melakukan analisis data yang dikumpulkan, ditemukan bahwa (1) penerapan manajemen mutu TPQ Darussalam Blokagung Tegalsari Banyuwangi baik. (2) kualitas sumberdaya pendidik TPQ Darussalam Blokagung Tegalasari
\end{abstract}


Jurnal Darussalam; Jurnal Pendidikan, Komunikasi dan Pemikiran Hukum Islam

Vol. IX, No 1: 47-65. September 2017. ISSN: 1978-4767 (Cetak), ISSN: 2549-4171 (Online)

Banyuwangi sangat baik. (3) ada pengaruh Penerapan Manajemen Mutu terhadap Kualitas Sumberdaya Pendidik TPQ Darussalam Blokagung Tegalsari Banyuwangi Tahun Pelajaran 2017 adalah sebesar 36,3\%.

\section{Kata Kunci: Manajemen Mutu, Sumberdaya Pendidik}

\section{A. Latar Belakang}

Suatu lembaga pendidikan haruslah mempunyai guru yang bermutu atau berkualitas agar menghasilkan peserta didik yang baik yang berkualitas. Oleh karena itu, perlu adanya manajemen peningkatan mutu pendidik. Guru merupakan salah satu faktor penting dalam pelaksanaan pendidikan disekolah, untuk meningkatkan mutu pendidikan bearti juga meningkatkan mutu guru, meningkatkan mutu guru bukan dilihat dari kesejahteraannya saja, teapi juga profesionalitas guru tersebut. Guru yang professional dalam menjalankan tugas diharapkan dapat meningkatkan mutu pendidikan serta menjadikan siswa menjadi manusia yang berkualitas dan berguna bagi nusa dan bangsa.

Guru sebagai ujung tombak pendidikan dituntut untuk memiliki komptensi seperti yang diharapkan oleh UU dan peraturan pemerintah. Tidak hanya itu guru harus aktif mengaktualisasi diri yaitu mengembangkan meteri pembelajaran yang diampu secara kreatif, berkompeten, mengembangkan keprofesionalan secara berkelanjutan dengan melakukan tindakan yang reflektif, dan mampu memanfaatkan teknologi informasi dan komunikasi untuk mengembangkan diri.

Beberapa permasalahan yang muncul dalam hal santri, masih ada santri yang minat belajar mengaji rendah, padahal ustadz dan ustadzah TPQ Darussalam Blokagung sudah layak untuk mengajar, hal ini ditandai dengan kepemilikan syahadah (sertifikat mengajar Al-Qur'an metode qiroati) data ini sesuai penuturan Ustadzah Latifah, Kepala TPQ Darussalam Blokagung (17 April 2017): "TPQ Darussalam Blokagung itu di bawah naungan yayasan pesantren Darussalam Blokagung, jadi pengasuhnya juga pengasuh pesantren Darussalam Blokagung yang kebetulan juga mendapat amanah sebagai anggota tim tashih qiraati cabang Banyuwangi, jadi pendidiknya mendapat perhatian khusus dalam kualitasnya, misalnya harus punya syahadah, alhamdulillah, ustadz dan ustadzah TPQ Darussalam Blokagung semua sudah memiliki syahadah, tapi ternyata 
Jurnal Darussalam; Jurnal Pendidikan, Komunikasi dan Pemikiran Hukum Islam

Vol. IX, No 1: 47-65. September 2017. ISSN: 1978-4767 (Cetak), ISSN: 2549-4171 (Online)

memang masih ada santri yang minat belajarnya rendah, diantara faktornya adalah rendahnya dukungan wali santri serta kesibukan wali santri sehingga kurang mendampingi santri dalam pendidikan al-Qur'an”.

Belum ada kelas khusus bagi santri yang kemampuannya di bawah standar, karena tidak semua santri memiliki kemampuan sama. Selain itu juga belum ada waktu khusus bagi santri yang di bawah standar untuk menambah pelajaran agar tidak terlalu jauh tertinggal kemampuannya dibanding teman tingkatnya. Hal ini seperti yang dituturkan Ustadz Gatot Supribadi pada hari jum'at 17 Maret 2017.

Belum adanya reward dan punishmant bagi santri atau ustadz dan sistem pendidikannya. Bagi santri atau ustadz ustadzah yang berprestasi belum mendapatkan penghargaan dari lembaga tersebut. Dan tidak ada juga ancaman atau peringatan bagi santri atau ustadz ustadzah yang melanggar peraturan, misalnya guru yang kurang aktif atau sering terlambat. Berdasarkan pengamatan awal, Taman Pendidikan Al-Qur'an yang disingkat menjadi TPQ. TPQ Darussalam Blokagung ialah TPQ yang berdiri dibawah naungan Yayasan Pondok Pesantren Darussalam, TPQ ini bertempat dikawasan Blokagung Tegalsari Banyuwangi. TPQ Darussalam Blokagung merupakan TPQ yang mempunyai jumlah santri terbanyak se-kabupaten Banyuwangi dengan jumlah 350 dan mempunyai indeks prestasi yang baik. Pernah menjadi juara 3 lomba Qiroati Nasional yang bertempat di Semarang sesuai dengan informasi dari Ustadzah Yaniah pada 15 Januari 2017.

Oleh karena itu penelitian tentang manajemen mutu yang diterapkan TPQ Darussalam Blokagung perlu untuk dilakukan, mengingat kualitas sumberdaya pendidik sangat mempengaruhi terhadap kuaitas peserta didik, dalam hal ini santri dan lulusan TPQ Darussalam Blokagung.

\section{B. Rumusan Masalah}

Sesuai dengan latar belakang yang telah diuraikan di atas, penulis dapat merumuskan sebagai berikut:

1. Bagaimana penerapan manajemen mutu TPQ (Taman Pendidikan AlQur'an) Darussalam Blokagung Blokagung Tegalsari Banyuwangi? 
Jurnal Darussalam; Jurnal Pendidikan, Komunikasi dan Pemikiran Hukum Islam

Vol. IX, No 1: 47-65. September 2017. ISSN: 1978-4767 (Cetak), ISSN: 2549-4171 (Online)

2. Bagaimana kualitas sumber daya pendidik TPQ (Taman Pendidikan AlQur'an) Darussalam Blokagung Blokagung Tegalsari Banyuwangi?

3. Adakah pengaruh panerapan manajemen mutu terhadap kualitas sumber daya pendidik TPQ (Taman Pendidikan Al-Qur'an) Darussalam Blokagung Blokagung Tegalsari Banyuwangi?

4. Seberapa besar pengaruh penerapan manajemen mutu terhadap kualitas sumber daya pendidik TPQ (Taman Pendidikan Al-Qur'an) Darussalam Blokagung Blokagung Tegalsari Banyuwangi?

\section{Tujuan Penelitian}

1. Untuk mengetahui penerapan manajemen mutu TPQ (Taman Pendidikan Al-Qur'an) Darussalam Blokagung Tegalsari Banyuwangi

2. Untuk mengetahui kualitas sumber daya pendidik TPQ (Taman Pendidikan Al-Qur'an) Darussalam Blokagung Tegalsari Banyuwangi

3. Untuk mengetahui pengaruh manajemen mutu terhadap kualitas sumber daya pendidik di TPQ (Taman Pendidikan Al-Qur'an) Darussalam Blokagung Tegalsari Banyuwangi

4. Untuk mengetahui besarnya pengaruh manajemen mutu terhadap kualitas sumber daya pendidik TPQ (Taman Pendidikan Al-Qur'an) Darussalam Blokagung Tegalsari Banyuwangi.

\section{Kajian Pustaka}

1. Pengertian Manajemen Mutu

Menurut Terry (2001 : 2) "manajemen adalah suatu proses atau kerangka kerja, yang melibatkan bimbingan atau pengarahan suatu kelompok orang-orang kearah tujuan-tujuan organisasional atau maksud-maksud yang nyata”. Sedangkan menurut Peters dan Agustin dalam Sallis (2012 : 29) "Mutu adalah sebuah hal yang berhubungan dengan gairah dan harga diri".

Dari pemaparan di atas manajemen mutu adalah suatu proses atau langkah kerja yang melibatkan bimbingan atau pengarahan kelompok orangorang kearah tujuan-tujuan organisasional atau maksud-maksud nyata dalam sebuah hal yang berhubungan dengan gairah dan harga diri. 
a. Sumberdaya Pendidik

1) Orientasi Perencanaan

Menurut Schuler dalam Salim (2013 : 98) pada perencanaan personalia, yang mencakup jumlah dan jenis keterampilan atau keahlian orang, ditempatkan pada pekerjaan yang tepat, pada waktu tertentu, yang dalam jangka panjang memberikan keuntungan individu dan organisasi. Jadi dari pemaparan diatas mengandung pengertian bahwa dalam perencanaan tenaga kependidikan mengandung analisis tentang kebutuhan tenaga kependidikan, baik dari segi kualitas maupun kuantitas.

2) Langkah-langkah Perencenaan

Haris dalam Salim (2013 : 99) mengemukakan lima langkah dalam pendekatan perencanaan dalam tenaga kependidikan, yakni; (1) mereview visi dan misi organisasi atau lembaga kependidikan; (2) mencermati isu-isu aktual yang bersifat internal; (3) menentukan masa depan organisasi atau lembaga pendidikan; (4) menentukan kapabilitas tenaga kependidikan dimasa yang akan datang; (5) menganalisis dan memutuskan kesenjangan diantara semua itu. Menurut Salam (2014:98), "Dalam perencanaan tenaga kependidikan ada empat langkah pokok, yaitu; (1) perencanaan untuk kebutuhan masa depan; (2) perencanaan untuk perkembangan masa depan; (3) perencanaan untuk perekrutan dan seleksi atau untuk pemberentian sementara; (4) perencanaan untuk pengembangan.

Jadi dari pemaparan diatas langkah-langkah perencanaan berguna untuk merencanakan visi dan misi lembaga pendidikan untuk mencermati isu-isu aktual, perencanaan perekrutan dan seleksi atau untuk pemberentian sementara serta untuk menentukan masa depan organisasi atau lembaga pendidikan.

3) Peramalan dan Audit Tenaga Kependidikan

1) Peramalan

Peramalan merupakan unsur pokok dalam perencanaan tenaga kependidikan, unsur tersebut memberikan kepada manajer 
pendidikan informasi yang dibutuhkan untuk merencanakan langkah-langkah lainnya dalam proses pengelolaan tenaga kependidikan. Menurut Abdu Salam (2014 : 100). "Peramalan tenaga kependidikan berupaya untuk menentukan tenaga apa yang dibutuhkan organisasi guna mempertahankan pertumbuhannya dan memanfaatkan peluang dimasa yang akan datang”.

Jadi dapat dipahami bahwa peramalan adalah unsur pokok dalam perencanaan tenaga kependidikan untuk mencari informasi yang dibutuhkan dalam proses pengelolaan tenaga kependidikan serta untuk mempertahankan pertumbuhan dan pemanfaatan peluang di masa yang akan datang.

2) Audit Tenaga Kependidikan

Audit tenaga kependidikan adalah unsur pokok dalam perencanaan tenaga kependidikan, unsur tersebut memberikan kepada manajer pendidikan informasi yang dibutuhkan untuk merencanakan langkah-langkah lainnya dalam proses pengelolaan tenaga kependidikan. Langkah kedua setelah peramalan dirampungkan adalah audit tenaga kependidikan. Menurut Abdu Salam (2014 : 101) Audit adalah "memperoleh informasi tentang pegawai yang kini ada dalam organisasi itu".

Dalam audit tenaga kependidikan, keterampilan dan prestasi masing-masing dalam organisasi itu dinilai. Untuk masing-masing bagian, individu disusun peringkatnya (rangking) menurut kualitas pekerjaan mereka. Informasi yang didapat akan memberikan kepada manajer pendidikan tingkatan gambaran tentang efektivitas dari staf pada tiap-tiap bagian.

Jadi dapat dipahami bahwa yang dimaksud dalam audit kependidikan ialah memperoleh inforfmasi tentang pegawai yang kini ada dalam organisasi itu sehingga informasi tersebut dapat memberikan gambaran pada manajer pendidikan tentang efektivitas dari staf pada tiap-tiap bagian. 
Untuk manajemen tingkat yang lebih tinggi, langkah selanjutnya dalam proses audit adalah mengembangkan rencana penggantian yang rinci atau bagan penggantian, perencanaan tenaga kependidikan mencakup dua kegiatan penting, yaitu:

Perencanaan dan peramalan

Perkiraan merupakan langkah awal yang dilakukan dalam perencanaan. Menurut Salmia dalam Abdu Salam (2014 : 102) ramalan merupakan "suatu langkah permulaan dalam proses perencanaan untuk menysusun satu rencana.Peramalan dalam koneks pengelolaan tenaga kependidikan diperlukan agar dalam melakukan pengadaan atau perekrutan tenaga kependidikan sesuai dengan kebutuhan organisasi, baik untuk saat ini maupun saat mendatang, baik jumlah, jenis, maupun kualifikasinya. Disamping itu dengan adanya peramalan atau analisis kebutuhan yang matang, maka organisasi akan terhindar dari tindakan inefisiensi.

Lebih lanjut dikatakan bahwa perencanaan merupakan bagian terpenting dalam kesuksesan. Kalau suatu aktivitas dilakukan tanpa didasari dengan perencanaan, maka tidak akan mendapatkan hasil maksimal. Oleh karena itu perencanaan harus dibuat dalam akifitas apapun.

Bagian terpenting dari perencanaan tenaga kependidikan adalah melakukan analisis terhadap kapabilitas organisasi atau lembaga pendidikan saat ini. Secara khusus, suatu organisasi pendidikan membutuhkan pengetahuan (informasi) tentang kualifikasi yang dibutuhkan oleh tenaga kependidikan untuk menduduki suatu pekerjaan atau jabatan.

Analisis jabatan merupakan pondasi bagi berfungsinya dan berjalannya aktivitas pengelolaan tenaga kependidikan lainnya. Secara mendasar, analisis jabatan sebagai syarat formal bagi pelaksanaan seleksi, penilaian performansi kerja, piagam pelatian dan pengembangan tenaga kependidikan, memberikan kompensasi, sampai pada pemberentian tenaga kependidikan. 
Jurnal Darussalam; Jurnal Pendidikan, Komunikasi dan Pemikiran Hukum Islam

Vol. IX, No 1: 47-65. September 2017. ISSN: 1978-4767 (Cetak), ISSN: 2549-4171 (Online)

4) Analisis Pekerjaan

Menurut Salam (2014 : 116) “Analisis pekerjaan merupakan proses membuat dan mencatat aspek-aspek pekerjaan yang dibutuhkan”. Secara rinci, analisis pekerjaan terdiri dari dua hal, yaitu: pertama, depeneitian pekerjaan, yang mencakup: (1) kewajiban-kewajiban atau aktivitas-aktivitas penting yang dijalankan; (2) tujuan-tujuan pekerjaan; (3) situasi-situasi dimana pekerjaan itu dilaksanakan; (4) standar dan karakteristik pekerjaan. Kedua, Spesifikasi pekerjaan yang mencakup; (1) skill; (2) pengetahuan; (3) kemampuan; (4) kepribadian; (5) kepentingan;(6) pereferensi.

Sejalan dengan tujuan umum dalam perencanaan tenaga kependidikan, yaitu untuk mengidentifikasi kebutuhan dan ketersediaan tenaga kependidikan, maka proses perencanaan tenaga kependidikan sebagaimana diungkapkan oleh Randall S. Schuller dalam Hasbuan (1996 : 237) melalui empat tahap penting, yaitu;

1) Mengumpulkan, menganalisis, dan meramalkan data tentaang kebutuhan dan ketersediaan tenaga kependidikan.

2) Menentukan tujuan perencanaan tenaga kependidikan, kebijakan-kebijakan serta keuntungan dan dukungan dari top manajemen

3) Merancang dan mengimplementasikan program-program seperti rekrutmen, pelatihan, dan promosi yang dapat meningkatkan prestasi kerja para tenaga

4) Mengawasi dan mengevaluasi rencana-rencana dan programprogram perencanaan tenaga kependidikan yang berjalan.

5) Spesifikasi Jabatan

Menurut Salam (2014 : 122) “Analisis atau desain pekerjaan adalah fungsi penetapan kegiatan kerja sesorang atau sekelompok tenaga secara organisasional". Tujuannya untuk mengatur penugasan kerja supaya dapat memnuhi kebutuhan organisasi. 
Menurut Riva'i dalam Salam (2014 : 124) mengemukakan empat langkah yang harus dilakukan dalam perencanaan tenaga kependidikan, yakni: (1) Perencanaan untuk kebutuhan masa depan; (2) Perencanaan keseimbangan untuk masa depan; (3) Perencanaan unuk pengadaan dan seleksi atau pemberhentian sementara: (4) Perencanaan untuk pengembangan.

Menurut Hariandja dalam Salam (2014 : 125) menyatakan bahwa perencanaan tenaga kependidikan itu harus melalui langkahlangkah berikut: (1) Peramalan kebutuhan sumber daya manusia; (2) Penentuan kebutuhan sumber daya manusia dimasa yang akan datang; (3) Analisis ketersediaan sumber daya manusia dan kemampuan lembaga pendidikan; (4) Penentuan dan implementasi program.

Secara operasional, proses perencanaan tersebut dilakukan aktifitas sebagai berikut:

a) Prosedur

(1) Melakukan analisis lingkungan, terutama terkait langsung masalah kekuatan yang akan mempengaruhi pasokan dan permintaan tenaga kerja.

(2)Analisis penilaian terhadap efektifitas kerja tenaga kependidikan yang ada. Untuk mengetahui efektifitas sumber daya manusia tersebut dapat diukur dengan keadaan sebagai berikut:

(a) Biaya tenaga kependidikan per satuan,

(b) Kompensasi dan presentase,

(c) Biaya departemen tenaga kependidikan dalam prosentase total biaya,

(d) Biaya untuk penerimaan tenaga kerja,

(e) Tingkat keluar-masuk pegawai,

(f) Tingkat ketidak hadiran,

(g) Biaya kompensasi tenaga kerja per pegawai.

b) Faktor-faktor yang menentukan perencanaan dan strategi organisasi, dapat diuraikan sebagai berikut:

(1) Strategi organisasi 
(2) Budaya organisasi

(3) Persaingan/lingkungan keuangan

(4) Kondisi organisasisaat ini

(5) Kebuuhan tenaga kependidikan

(6) Sumber keuangan yang tersedia

c) Menyusun strategi organisasi, dengan sasaran utama kepada tenaga kependidikan yang memiliki:

(1) Nilai, yaitu tenaga kependidikan yang peka terhadap ancaman dan peluang dari luar, sehingga mampu membuat keputusan dan inovatif terhadap perubahan lingkungan

(2) Keunikan, yakni kemampuan khusus orang-orang dalam organisasi yang dapat memberikan keuntungan besar

(3) Kemampuan untuk mencontoh, mereka tidak mudah ditiru orang lain

(4) Organisasi, manusia harus diorganisir agar memiliki daya saing.

d) Proses, melalui:

(1) Analissi strategi atau analisis kerja, yakni mempelajari jalannya pekerjaan, aktivitas, konteks dan output dari suatu pekerjaan

(2) Pengembangan rencana, yakni meliputi: keahlian, kemampuan kerja, lowongan yang tersedia, promosi dan pemindahan/cuti atau pemberhentian

(3) Evaluasi rencana, yakni kesiapan untuk perencanaan tenaga kependidikan

(4) Analisis lingkungan eksternal, meliputi; kebijakan pemerintah, masalah kependudukan dan persaingan, kondisi perekonomian secara makro, komposisi dan pola kehidupan tenaga kerja pada umumnya

(5) Analisis lingkungan internal, dilakukan auditing pekerjaan dan keahlian dan kemampuan inventarisasi organisasi 
(6) Sifat analisis pekerjaan, yakni mendefinisikan pekerjaan atau mengelompokkan tugas-tugas dan tanggungjawab.

e) Analisis pekerjaan, terutama ditujukan untuk menguraikan pekerjaan dan spesifikasi jabatan. Dalam analisis pekerjaan, dilakukan tahapan-tahapan sebagai berikut:

(1) Perencanaan analisis pekerjaan, dengan cara:

(a)Mengidentifikasi sasaran dari analisis pekerjaan

(b) Mendapatkan dukungan menejamen puncak

(2) Mempersiapkan dan mengkomunikasikan analisis pekerjaan:

(a)Mengidentifikasi pekerjaan dan metodologi

(b) Mengkaji dokumentasi pekerjaan yang ada

(c) Mengkomunikasikan proses kepada manajer pendidikan dan tenaga

(3) Melakukan analisis pekerjaan, yaitu:

(a) Mengumpulkan data analisis pekerjaan

(b) Mengkaji dan menyusun data

(4) Mengembangkan uraian dan spesifikasi pekerjaan, yaitu:

(1) Mengkonsep uraian dan spesifikasi jabatan

(2) Mengkaji konsep

(3) Mengidentifikasi rekomendasi-rekomendasi

(4) Finalisasi uraiann dan rekomendasi pekerjaan

(5) Mempertahankan dan memutakhirkan uraian pekerjaan, yakni:

(1) Memutakhirkan uraian dan spesifikasi pekerjaan sesuai perubahan organisasi

(2) Secara berkala mereview semua pekerjaan

Setelah menganalisa pekerjaan dan spesifikasi jabatan,langkah selanjutnya adalah pengambilan keputusan perencanaan tenaga kependidikan. Keputusan-keputusan perencanaan tersebut berupa:

(1) Keputusan perencanaan tenaga kependidikan, yakni berupa banyak pegawai yang dibutuhkan, kapan dibutuhkan, 
pengetahuan, keterampilan dan kemampuan apa saja yang dibutuhkan dan kualifikasi khusus

(2) Keputusan perekrutan strategis, yaitu: dimana untuk merekrut, dari kalangan inernal atau eksternal, untuk siapa perekrutan serta bersifat dasar untuk persyaratan

(3) Metode/sumber perekrutan, apakah melalui pilihan periklanan atau aktivitas perekrutan-perekrutan.

\section{E. Metode penelitian}

Jenis Penelitian ini deskriptif kuantitatif. Populasi yang digunakan dalam penelitian ini bersifat penelitian populasi karena jumlah subjek kurang dari 100 . Teknik Pengumpulan Data yang digunakan adalah observasi, angket dan dokumentasi. Validitas data menggunakan rumus korelasi product moment. Reliabilitas data menggunakan rumus Alpha. Uji normalitas data menggunakan rumus Kolmogorof Smirnov. Analisis data menggunakan rumus regresi linier sederhana.

\section{F. Pembahasan}

1. Pengaruh Penerapan Manajemen Mutu (X)

Sesuai dengan apa yang diuraikan pada bagian sebelumnya bahwa permasalahan pertama yang dipertanyakan dalam penelitian ini adalah bagaimana penerapan manajemen mutu terhadap kualitas sumberdaya pendidik di TPQ Darussalam Blokagung Tegalsari Banyuwangi Tahun Pelajaran 2017, maka hasil penelitian ini menunjukkan bahwa Berdasarkan uji $\mathrm{t}$ diperoleh hasil hitung manajemen strategik (X) sebesar 21,883 dibandingkan $t$ tabel dengan $\mathrm{N}=25-2$ taraf signifikansi $5 \%=2,052$ dan $\mathrm{t}$ tabel dengan $\mathrm{n}=25-2$ taraf signifikansi $1 \%=$ 2,771, menghasilkan hasil uji t hitung > t tabel, maka Ha diterima, jadi hasil penelitian ini menunjukkan bahwa penerapan manajemen mutu yang diterapkan TPQ Darussalam Blokagung Tegalsari Banyuwangi Tahun Pelajaran 2017 tergolong baik. 
Jurnal Darussalam; Jurnal Pendidikan, Komunikasi dan Pemikiran Hukum Islam

Vol. IX, No 1: 47-65. September 2017. ISSN: 1978-4767 (Cetak), ISSN: 2549-4171 (Online)

2. Kualitas Sumberdaya Pendidik (Y)

Sesuai dengan apa yang diuraikan pada bagian sebelumnya bahwa permasalahan kedua yang dipertanyakan dalam penelitian ini adalah bagaimana kualitas sumberdaya pendidik TPQ Darussalam Blokagung Tegalasari Banyuwangi Tahun Ajaran 2017, maka hasil penelitian ini menunjukkan bahwa pada uji t diperoleh hasil hitung variabel kualitas sumberdaya pendidik (Y) sebesar 1,382 dibandingkan $\mathrm{t}$ tabel dengan $\mathrm{N}=25-2$ taraf signifikansi 5\% $=2,052$ dan $\mathrm{t}$ tabel dengan $\mathrm{N}=25-2$ taraf signifikansi $1 \%=2,771$, menghasilkan hasil uji $\mathrm{t}$ hitung > t tabel, maka Ha diterima, jadi hasil penelitian ini menunjukkan bahwa kualitas sumberdaya pendidik TPQ Darussalam Blokagung Tegalasari Banyuwangi Tahun Pelajaran 2017 baik.

3. Pengaruh Manajemen Mutu (X) Terhadap Kualitas Sumberdaya Pendidik (Y) Permasalahan ketiga yang ingin dijawab dalam penelitian ini adalah pengaruh penerapan manajemen mutu $(\mathrm{X})$ terhadap kualitas sumberdaya pendidik (Y). Berdasarkan hasil uji $\mathrm{F}$ diperoleh hasil bahwa $\mathrm{F}$ hitung yaitu, 478.860 dibandingkan t tabel dengan $\mathrm{N}=25-2$ taraf signifikansi $5 \%=2,052$ dan $\mathrm{T}$ tabel dengan $\mathrm{N}=25-2$ taraf signifikansi $1 \%=2,771$ menghasilkan hasil uji $\mathrm{F}$ hitung $>\mathrm{F}$ tabel, maka Ha diterima, yang berarti variabel bebas, yaitu pengaruh penerapan manajemen mutu (X) secara simultan atau bersama-sama memiliki pengaruh signifikan terhadap variabel terikat sumberdaya pendidik (Y).

4. Pengaruh Manajemen Mutu (X) Terhadap Kualitas Sumberdaya Pendidik (Y)

Hasil penelitian menunjukkan bahwa manajemen mutu (X) mempunyai pengaruh yang besar terhadap kualitas sumberdaya pendidik (Y) sebesar 95,4\%, sisanya $4,6 \%$ dipengaruhi oleh variabel lain

\section{G. Kesimpulan}

Berdasarkan hasil penelitian dan analisis data sebagaimana diuraikan pada bab sebelumnya dapat disimpulkan sebagai berikut:

1. Berdasarkan tabel hasil analisis uji t tersebut dapat ditarik kesimpulan bahwa pada variabel manajemen pendidikan (X) t hitung yaitu 21.883 dibandingkan $\mathrm{t}$ tabel dengan $\mathrm{N}=25-2$ taraf signifikansi $5 \%=2,069$ dan $\mathrm{t}$ tabel dengan $\mathrm{N}=25-2$ taraf signifikansi $1 \%=2,807$, menghasilkan hasil 
Jurnal Darussalam; Jurnal Pendidikan, Komunikasi dan Pemikiran Hukum Islam

Vol. IX, No 1: 47-65. September 2017. ISSN: 1978-4767 (Cetak), ISSN: 2549-4171 (Online)

uji $\mathrm{t}$ hitung > t tabel, maka Ha diterima, jadi hasil penelitian ini menunjukkan bahwa penerapan manajemen mutu yang diterapkan TPQ Darussalam Blokagung Tegalsari Banyuwangi tahun pelajaran 2017 tergolong baik.

2. Berdasarkan uji $\mathrm{t}$ diperoleh hasil hitung variabel kualitas sumberdaya pendidik (Y) sebesar 1,382 dibandingkan t tabel dengan $\mathrm{N}=25-2$ taraf signifikansi $5 \%=2,052$ dan $\mathrm{t}$ tabel dengan $\mathrm{N}=25-2$ taraf signifikansi $1 \%$ $=2,771$, menghasilkan hasil uji t hitung $>\mathrm{t}$ tabel, maka Ha diterima, jadi hasil penelitian ini menunjukkan bahwa kualitas sumberdaya pendidik TPQ Darussalam Blokagung Tegalasari Banyuwangi Tahun Pelajaran 2017 baik.

3. Berdasarkan hasil uji $\mathrm{F}$ diperoleh hasilbahwa $\mathrm{F}$ hitung yaitu, 478.860 dibandingkan $\mathrm{t}$ tabel dengan $\mathrm{N}=25-2$ taraf signifikansi $5 \%=2,052$ dan $\mathrm{t}$ tabel dengan $\mathrm{N}=25-2$ taraf signifikansi $1 \%=2,771$ menghasilkan hasil uji $\mathrm{F}$ hitung $>\mathrm{F}$ tabel, maka Ha diterima, yang berarti variabel bebas, yaitu pengaruh penerapan manajemen mutu $(\mathrm{X})$ secara simultan atau bersamasama memiliki pengaruh signifikan terhadap variabel terikat sumberdaya pendidik (Y).

4. Berdasarkan hasil yang tersaji pada tabel tersebut di atas diketahui bahwa nilai $\mathrm{R}$ atau koefisien korelasi sebesar 0,977, sedangkan nilai $\mathrm{R}$ Square, hasil pengkuadratan nilai $\mathrm{R}$ atau koefisien determinasi (KD) sebesar 0,954, yang dapat diartikan bahwa variabel bebas $\mathrm{X}$ memiliki pengaruh kontribusi sebesar 95,4\% terhadap variabel $\mathrm{Y}$ dan 4,6\% lainnya dipengaruhi oleh faktor-faktor lain diluar variabel X.

Dengan demikian ada pengaruh penerapan manajemen peningkatan mutu terhadap kualitas sumberdaya pendidik TPQ Darussalam Blokagung Tegalsari Banyuwangi sebesar 95,4\%, sedangkan sisanya $4,6 \%$ dipengaruhi oleh variabel lain.

\section{H. Saran}


Sehubungan dengan hasil penelitian dan kesimpulan tersebut di atas, dapat disampaikan beberapa saran kepada pengelola TPQ dalam hal ini kepala TPQ dibantu dengan semenap pengurus di dalam lembaga tersebut, sebagai berikut:

1. Lembaga TPQ Darussalam diharapkan selalu memantau lingkungan dengan baik yang berada diluar maupun didalam agar dapat memberikan gambaran keadaan TPQ terkait pencapaian tujuan yang diinginkan, dan dapat dimodifikasi dimasa depan karena faktor-faktor eksternal dan internal yang selalu berubah

2. Lembaga TPQ Darussalam diharapkan mampu meningkatkan kualitas pendidikan (input, proses, dan output) yang dimilikinya dengan menerapakan manajemen mutu dengan sebaik mungkin, mulai dari tahap formulating, implementing sampai tahan evaluating, sehingga mampu mentransformasikan tujuan mutu kedalam aksi yaitu menyelenggarangkan program TPQ, baik jangka pendek, menengah ataupun panjang yang sesuai dengan tujuann organisasi dan kebutuhan lingkungannya

3. Penerapan manajemen mutu dan kualitas sumberdaya pendidik sangat berpengaruh sehingga keduanya harus saling beriringan dalam peningkatan kinerja, sehingga lembaga dapat mencapai hasil sesuai yang diinginkan.

4. Berkaitan dengan hasil penelitian mutu pendidikan $95,4 \%$ dipengaruhi oleh variabel manajemen strategik dan sisanya 4,6\% dipengaruhi oleh variabel lain, diharapkan bagi peneliti selanjutnya untuk melakukan penelitian terkait tema yang sama yakni penerapan manajemen mutu dengan indikator yang berbeda, agar dapat mengungkap 4,6\% variabel lain yang mempengaruhi peningkatan sumberdaya pendidik, Penulis berharap semoga penelitian ini bisa dijadikan acuan dalam penelitian selanjutnya.

\section{Daftar Pustaka}

Hasibuan, Malayu S.P. 2000. Manajemen Sumber Daya Manusia. Jakarta: Bumi Aksara. 
Jurnal Darussalam; Jurnal Pendidikan, Komunikasi dan Pemikiran Hukum Islam

Vol. IX, No 1: 47-65. September 2017. ISSN: 1978-4767 (Cetak), ISSN: 2549-4171 (Online)

Hasibuan, Melayu S.P. 2008. Manajemen: Dasar, Pengertian, dan Masalah. Jakarta: Bumi Aksara

Husien, Latifah. 2016. Profesi Keguruan Menjadi Guru Profesional. Yogyakarta: Pustaka Baru Press

Nata Abuddin, M.A. 2010. Ilmu Pendidikan Islam. Jakarta: PT. Fajar Interpratama Mandiri.

Sallis, Edward. 2006. Total Quality Management in Education (manajemen Mutu pendidikan). Jogjakarta: IRCISoD.

Soetjipto dan Kosasi, Raflis. 2011. Profesi Keguruan. Jakarta: Rineka Cipta.

Stoner, James AF. dan Freeman, R. Edward. 2008. Manajemen. Jakarta: Intermedia.

Sugiyono. 2009. Memahami Penelitian Kualitatif. Bandung: Alfabeta.

Suharsaputra,Uhar. 2016. Metode Penelitian Kuantitatif, Kualitatif, Dan Tindakan. Bandung: Refika Aditama.

Terry, George R \& Rue, Leslie W. 2014. Dasar-Dasar Manajemen. Jakarta: PT. Bumi Aksara.

Tjiptono Fandy \& Diana Anastasia. 2001. Total Quality Manajement. Jogjakarta: C.V Andi Offset.

Tunggal, Amin Wijaya. 1993. Manajemen Muru Terpadu. Jakarta: Rineka Cipta. 